\title{
GENERATIONAL DIFFERENCES IN ADULT EDUCATION METHODOLOGY - THE POINT OF VIEW OF THE INSTRUCTORS
}

\author{
Szilárd Malatyinszki \\ Kodolanyi Janos University, Hungary
}

The methodology of adult learning has changed significantly. Today, it is no longer possible to consider it a homogeneous group of trainees with a significant age difference. Different methods and tools are available to acquire knowledge. Digital technology, changes in time management, and changes in the way information is processed require new methods in adult learning. The acquisition of knowledge is necessary to enable workers to contribute to the digitization of the operating characteristics of production equipment and machinery in the context of Industry 4.0 and, on the other hand, to enable the combination of robotic and human skills to be launched in the $21^{\text {st }}$ century through Industry 5.0. In our research, we examine the perspectives of adult education institutions, adult education professionals, and the people involved in adult education to ameliorate the use of digital technology in adult education as effectively as possible. We looked at the readiness and openness of institutions and trainers and the digital competencies and expectations of adult learning users of different generations. With our research, we got to know the situation of adult education enterprises operating in Hungary, in the Békés County, the needs and learning habits of different generations, and determined the directions of digital competence development in adult education.

Keywords: adult education, digital technology, digital competence, digitalization, education methodology

\section{Introduction}

One of the biggest challenges of the $21^{\text {st }}$ century is how to adapt to change most quickly. Globalization, Industry 4.0, the renewal of knowledge and technologies require a continuous and permanent transformation of industry and services. The assets around us are changing faster and faster, their lifespan is getting shorter and shorter, so their design and implementation requires shorter and shorter cycles - the product life cycle is getting shorter. Today, more than $50 \%$ of working people in Europe are in the service sector thanks to robotization. Services are being transformed, automated, with algorithms taking over one step at a time. Some examples: chatbots are being integrated into bank customer services, digital assistants are being added to doctors' offices, and hotel bookings are mostly made via apps rather than over the phone. This transformation requires a rapid renewal of the theoretical and practical skills of employees. Programming and servicing a machine, learning service, or a program as quickly as possible gives them a competitive advantage over their competitors. A competition that is no longer confined to a small environment, but can come from a neighbouring country or continent. Production will be located as close as possible to the place of use, depending on the raw material, but electronic services can be provided anywhere in the world thanks to digitalization. Customer service, the installation, and operation of a back-office banking operation or a business management system is no longer a fixed activity. This process is nothing less than coordinating the knowledge of the masses, increasing market efficiency through information and communications technology (Cséfalvay, 2017). The competitiveness of each region or country depends on the flexibility and speed with which we enable and equip students and adults drop out of education and training systems to change and adapt their skill structures. Different generations respond to change in different ways. Our grandparents and parents learned differently a few decades ago, with different tools, different information, different methods, and our children will learn differently in the future. Of course, they gather information with divergent tools, change professions at different speeds, and have different attitudes to new things. Their interaction and communication with digital tools will be diverse, and they will have different goals and different ways of managing and controlling them. Cooperation and thinking together between these generations is the key to progress, both in education and at work. Our research aims to investigate the specificities of teaching different generations in out-of-school education (Földházi, 2018). We want to provide answers to the question of what tools and methods are worth using to teach different generations. In addition, we will examine whether adult education institutions and adult educators have the technical equipment and methodological knowledge elements necessary for the successful implementation of this process. Our third area of research is whether it would be appropriate to integrate or segregate the teaching and learning of adults to achieve success (Meretei, 2017; Szücs, Törőcsik and Bittner, 2015). Can two or three generations be successfully educated together? What is needed to enable today's Generation Z to absorb knowledge quickly and adapt? Both generational research and adult learning techniques have a long tradition at international level. Countries with a long tradition in adult learning research include Estonia, Finland (Skorobogatov, 2015; Jogi and Gross, 2009; Jõgi et al., 2018; Blomqvist et al., 2000). Generational research has gained momentum since the 2000s, which includes categorising generations, their characteristics and analysing them in terms of activities (Brady and Elms, 1999; Windship and Harding, 2008; Elias and Stoker, 2014).

Our research was conducted in Hungary, within the framework of the Scientific Council of the Békés County Government Office's Employment, Labour, and Occupational Safety Department and its Labour Market Section, and the Kodolányi János University from November 2020 to April 2021. The Office assisted in the survey of experts and adult education participants for the sample, while the University provided methodological background and processing support for the research. In our research, we formulated different hypotheses for two target groups (adult education institutions and adult education staff). Our aim in investigating both target groups was to find out: is the methodology of the adult education system suitable to deal with the digital revolution? Is the adult learning market capable of moving away from the traditional frontal mode of information delivery and away from printed textbooks and notes? 


\section{Material and methods}

\section{Our hypotheses about adult learning trainers and institutions (providers)}

Adult learning practitioners are aware that trainees from younger age groups (mainly young people, but also increasingly from more mature age groups) are more aware of "moving" in the online space, but have not yet moved away from the traditional framework in terms of methodology.

Adult education trainers are not keeping pace with modern technology and methodological developments as they age, and are less able to meet the needs of different generations.

Adult learning institutions are not keeping up with digital technology and lack the tools, methods, and curricula structures needed to gather information from different generations.

During the adult education process, trainers use traditional teaching methods, and adult education institutions do not have electronic learning materials or tools to meet the needs of different generations.

As teachers get older, their ability to deliver differentiated education and keep up with digital technologies becomes less and less.

In the context of our secondary research, we present the structure of training in Hungary to summarize the role and importance of adult education.

We conducted our research in the Békés County, Hungary, using online questionnaires. All responses were voluntary and anonymous. The questionnaires were completed by three target groups covering the spectrum of adult education: adult learning companies and their trainers.

The total of 68 adult education staff members and 11 adult education experts completed the questionnaire. In the Békés County, in Hungary, this sample size exceeds $70 \%$ of the total population, both in adult education and adult education experts. The questionnaire started with demographic data and proceeded with the investigation of conscious use of the online space by the age groups involved in the training. We asked them about the tools and methods used by adult learners and adult learning practitioners and their ability to differentiate. Our questions included attitudes towards digital technologies. We applied a univariate analysis based on statistical methods to examine the distribution of the target group's opinions by age group. We used continuous and discrete variables depending on the type of question.

We complemented our research with the experience of the Employment, Labour, and Occupational Safety Department of the Békés County Government Office. The employment department of the government officials acting as an employment body and the employment departments of the district offices operate a system of labour market training outside the school system.

\section{Results and discussion}

The definition of a generation is based on the sociological perspective, according to which "a generation is a group of people born in the same era, shaped and bound together by specific events, trends and processes. Being part of a generation, therefore, means that contemporaries live in the same historical period and geographic location and share similar values" (Komár, 2017).

The real problem for the generation $Z$ is the lack of companionship, the lack of tolerance for failure, the lack of fulfilment, and the need to balance success-work-life. The constant desire for possession can be satisfied by more and more money and work, which overshadows the genuine development of individual and family goals. There is a particular risk of loneliness, depression, and deviance (Pais, 2021).
We divided the professionals into two groups, with separate questionnaires for training organizers and trainers in training institutions and adult learning experts.

We included a part of the questions in both questionnaires, such as their level of education, age group, the experience of adults in specific age groups in using online space, use of tools/methods in adult education, and the suitability of trainers in specific age groups to deliver differentiated instruction, the relationship between the use of differentiated teaching methods and the age of the instructor, the possibilities for simultaneous teaching of adults from different age groups and/or with different motivation/abilities, the upto-date use of digital technologies by adult education institutions and adult education instructors, and the needs of instructors to learn differentiated teaching methodologies and methodological support. We also asked all the professionals whether laying down a "level assessment package" would be a suitable and appropriate tool for training participants to determine their digital awareness and digital skills in their consideration.

We also asked teachers about the length of their teaching experience, the age range of the adults involved in their teaching work, and their suitability for delivering differentiated teaching. As regards the experts, we also asked them whether they felt qualified to provide methodological support for adult education institutions in the field of differentiated education, whether they had received training in this field in the context of further training for experts, and whether they had any need for additional training in this field in the context of further training for experts.

We sent our request to participate in the research to 37 adult education institutions and 13 adult education experts in the Békés County listed in the Pest County Government Office register.

Among the training institutions, 19 are located in the Békés County, 9 of them are regularly included in the training list of the Department of Employment, Labour and 0ccupational Safety of the Békés County Government Office, and they also organize labour market training for job seekers and adults in public employment in the Békés County. We also contacted all the non-county-based institutions on the training register, 18 in number.

The total of 68 respondents from training institutions and 11 experts completed the questionnaire. $84 \%$ (57) of the professionals in the training institutions work as trainers and $16 \%$ (11) as training organizers in the field of adult learning. The age distribution of the trainers is as follows: $5.9 \%$ aged $26-36,30.9 \%$ aged $37-46,39.7 \%$ aged $47-60$ and $23.5 \%$ aged $60+.6$ of the 11 experts interviewed are aged $60+, 3$ are aged $37-46$ and only 2 are aged 47-60.

For adults in all three age groups under 46 , more than $90 \%$ of professionals confirmed having a smartphone. The highest rate was among respondents under the age of 25 , at $98.7 \%$. There is a more significant drop in this rate for those aged $47-60$, with almost $2 / 3$ of respondents saying they use a smartphone for learning purposes. Among those aged 60 and over, only one in four say they use a smartphone.

Similarly, for the ability and suitability to use basic IT tools, the percentage of responses decreases steadily with increasing age and is lower (or just about the same) as the percentage calculated for the previous question. We see from the respondents' answers that having a smartphone, especially for older generations, does not mean that they are competent using it or other basic IT tools.

There is a similar declining trend in the age of adults in training in terms of accessing information from online platforms. $90-92 \%$ of respondents were confident that those under 37 years of age could learn online, while only $2 / 3$ of those aged $37-46$, nearly $1 / 3$ of those aged $47-60$, and only $11 \%$ of those aged $60+$ thought so. 


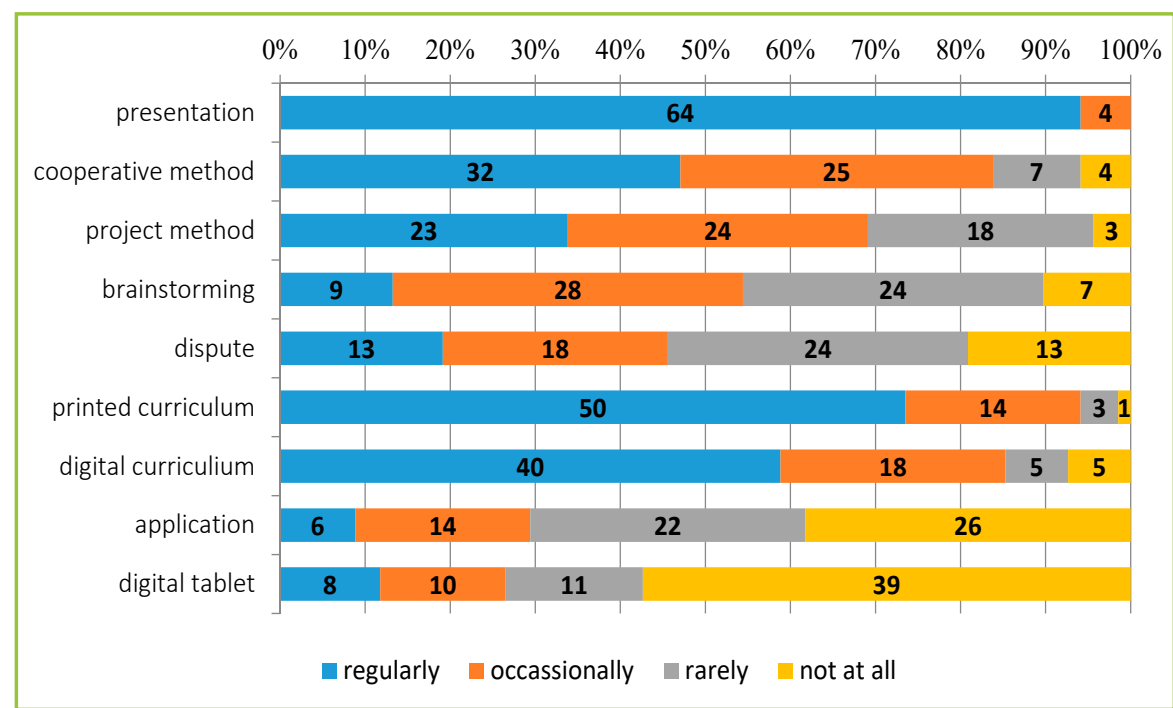

Figure 1 The regularity of the use of certain tools and methods in adult education - based on the responses of trainers (number and percentage of responses) Source: from our research, own editing

In the proportions calculated from the answers to the questions on the need to use a computer and to read from paper/book, we saw an inverse trend with advancing age. According to respondents, adults are less likely to use computers as they increase in age. More than $80 \%$ of respondents aged under 37 , just over $2 / 3$ of respondents aged 37-46, around $1 / 4$ of respondents aged $47-60$, and only $4 \%$ of respondents aged $60+$ answered 'yes' to this question.

The propensity to read from paper/book is very low among people under 25 , with only $5 \%$ of respondents saying that this is a characteristic of young people. Among the 26-36-year-olds, $23 \%$ of respondents, $57 \%$ of $34-46$-year-old respondents, and around $90 \%$ of respondents older than that age group think they like to access information on paper.

Experts assessed 9 methods/tools in terms of the use of different teaching methods/tools. Training institution professionals responded on the regularity with which they use these methods/ tools in their work as trainers in adult education, and experts responded on the regularity with which they think trainers use them in their work in adult education.

Everyone uses presentations, $93 \%$ of them on a regular basis. There was one negative answer for printed course material, $74 \%$ use paper course material regularly and $21 \%$ occasionally.

In terms of their use, the project method, the cooperative method, and digital learning materials are also popular among teachers, with only $4-7 \%$ saying they do not use them. For these three methods/tools, there seems to be a significant difference in terms of regularity. The percentage of regular users for the digital curriculum is $59 \%$ and $47 \%$ for the cooperative method, but the project method is also used regularly by $1 / 3$ of the trainers.

$81 \%$ of respondents use the debate method, but only $20 \%$ use it regularly. $62 \%$ of the teachers also use an app in their teaching, but only $9 \%$ of the teachers use it regularly. The least used tool of all those listed in the questionnaire was the digital whiteboard, which $43 \%$ of the respondents use, although only $12 \%$ use it regularly.

Both experts and trainers responded to the research question on whether they believe that trainers in each age group are able and suitable to deliver differentiated (methodologically adapted to the participants' abilities) adult learning.

Based on the combined responses of experts and trainers, trainers in the 25-36 and 37-46 age groups are most likely to be considered suitable for differentiated teaching, with 75-77\% saying they are either fully or mostly suitable. For these two age groups, $18 \%$ said their ability to meet this challenge varies, with 3-5 respondents unable to state a position.

About a half of the respondents in the 18-25 and 47-60 age groups considered that they were either fully or mostly suitable for differentiated teaching, and a third indicated that they were suitable to a varying extent. Here again, some could not form an opinion on suitability.

Just over a third of respondents over the age of 60 think they are fully or mostly qualified for this role, another third think they are variable, and a further $19 \%$ did not want to or could not answer this question. The proportion of respondents who say they are slightly suitable is highest in this age group at $15 \%$.

Teachers also assessed their own suitability for implementing differentiated teaching. A half of the respondents said they were fully capable, and a further $43 \%$ considered themselves more capable of delivering differentiated instruction. Only 4 respondents put themselves in the "variable" category in this respect and 1 respondent did not consider themselves suitable.

The number of people choosing full and greater partial eligibility is similar across age groups, with no significant difference.

Fifty-four \% of respondents agree that methodological knowledge is significantly dependent on practical experience, and $41 \%$ agree that the methodological knowledge required for differentiated instruction increases with age. Ten professionals (9 trainers and 1 expert) ticked both response options.

Only eight (10\%) said that this methodological knowledge decreases with age. Thus, overall, a half of the respondents (40) assume that the teacher's age has an influence on how differentiated teaching is applied. Most of them believe that the increase in age has a positive effect on this ability. Twenty professionals (25\%) believe that this methodological knowledge is also a function of theoretical/scholastic knowledge.

Tracking the development of digital technologies seems to be less of a problem from the responses, but more than a half of the respondents also think that the attitudes and equipment of adult learning institutions are very different. Slightly more than a third of respondents also say that the use of digital technologies in education depends on the financial resources of the institutions.

$82 \%$ of professionals think that adult learning professionals are able to keep up with digitalization, with a larger proportion (64\% of all respondents) choosing the category "rather yes". None of the respondents marked "not suitable", and only five chose "rather not". 3 said they could not judge.

In the next part of the questionnaire, we looked at the possibility and perceptions of different age groups and adults with different motivations/abilities to study in the same training course at the same time. On a scale of one to ten, 79 adult education professionals rated the feasibility of simultaneously educating a group of adults of heterogeneous age and/or ability. A score of one indicated 'not at all' and a score of ten indicated full agreement. 
$28 \%$ of respondents are less ( 5 or below) able to imagine teaching adults of different abilities and motivations at a time. A half of these respondents indicated the score of 5 .

$72 \%$ of professionals selected the score above 5 (tend to agree), there is minimal variation in the number of responses from 6 to 9 , and $25 \%$ of all respondents could fully (10 points) imagine simultaneous education of heterogeneous groups. The average of the responses was 7.2.

We also asked how important it is to teach different age groups and individuals with varying motivation/skills using different methodologies. Eighty-nine \% of respondents (70 respondents, including all experts) agree that adults from heterogeneous groups according to age or existing knowledge/motivation should be taught using different methods. Several of them also marked different answer options starting with "yes", giving the total of 83 marks for the pre-defined answers indicating agreement. Two of the eight main respondents who gave other answers also gave a clear "yes" answer, accompanied by a self-written explanation as follows:

$\square$ "Yes, but only a limited number (2-4) of different needs can be met to a high standard."

$\square$ "Yes, differentiation is important, but it is not always feasible, often the conditions are not there."

Even though the great majority of respondents agree with the need for differentiated teaching methods, they typically ( $58 \%$ of them) only use methods that are suitable for the majority of the trainees. Thirty-two \% of respondents indicated the need to apply a methodology tailored to each student, and only $15 \%$ stated that although it is essential to use differentiated methods, it is not feasible to start homogeneous groups.

Learning about the subject is an integral part of using modern differentiated teaching methods. We also considered it relevant to know-how and why experts and trainers are motivated to increase their methodological knowledge.

Respondents could tick more than one of the pre-defined response options in the knowledge acquisition and enhancement survey. Most of them are trying to improve their knowledge of teaching methods. Eighty $\%$ of teachers read professional materials available on the Internet, while the percentage of those reading printed literature is slightly below $50 \%$.

There is a wide use of consultation and peer learning, for example sharing good practices, joint project work, etc., $60 \%$ have also participated in training on the subject. Only two respondents answered the question negatively.

Around $3 / 4$ of trainers need information and methodological support for teaching adults of different age groups and with different motivations/ skills. Out of 11 experts, 10 participants responded that their experience shows that there is a need for methodological support from adult education institutions concerning the teaching of adults with different age groups and different motivation/skills.

Ten of the experts said that they would be ready to help if an adult education institution approached them directly to provide methodological support for differentiated adult learning. Three respondents chose the category "fully" and seven respondents chose the category "rather yes". Only one person ticked "rather no".

All the experts ( 9 of them fully) consider it necessary to receive information on the education of adults of different age groups and with different motivation/skills during the training of experts. Nine responded 'yes' to the question that they had received information on this topic during peer training.

At the end of the questionnaire, we also asked experts and trainers whether they thought it would be possible to create a "level assessment package" that would be a suitable and appropriate tool for trainees to determine their digital awareness and digital skills. Sixty-five (82\%) answered "yes", 8 "no" and 6 other comments were given as follows:

$\square$ "For the time being, I don't know. What should ordinary students do who don't have IT equipment at home?"

$\square$ "Yes, but the question is, what is it good for? It makes sense if it can be combined with appropriate competence development (financial/personal)."

$\square$ "Then there would not be many people in the courses because they could hardly read or write."

$\square$ "Yes, assessment is important, but a separate "package" is not needed, it can be quickly measured with a few questions. A higher level of preliminary assessment may be necessary for training courses where the field of specialization in IT."

$\square$ "An individual assessment depending on the nature of the training would be necessary."

$\square$ "In some cases, it would be justified. Otherwise, yes."

\section{Scope of results}

According to feedback from educators and experts, the conscious use of online space is prominent in the young age group, and our research shows that it decreases from the age of 40, probably also due to a decline in ICT skills. A significant proportion of the under-50s is able and capable of using ICT tools and can gather information from such tools. However, above the age of 60 , even if they have the necessary tools, a significant proportion is not able to use digital interfaces and is reluctant to use computers. From a methodological point of view, it is interesting to note that people over the age of 30 still like to read from paper and books, so they can be taught and trained well and effectively from notes and books.

Instructors - at least in the area covered by our research - make relatively frequent use of both print and digital learning materials, but digital whiteboards and apps are not yet available in adult education in significant numbers. From a methodological perspective, frontal teaching is dominant, compared to the cooperative and project method, discussion, and brainstorming.

Trainers and participants perceived that the methodological knowledge needed for differentiated teaching is less dependent on the age of the trainer and develops more with individual learning and experience. Based on the feedback from trainers, only 5 trainers indicated that a homogeneous methodology is sufficient for everyone, while the majority of trainers felt that adults of different ages, motivations, and abilities need different methodologies. The responses suggest that this differentiation is feasible in a large majority of adult education institutions, as the methodological knowledge is available on the part of the trainers. Online professional materials and face-to-face consultation with other colleagues are at the forefront in developing methodological knowledge. The availability of printed literature and the possibility of organized continuing training are also outstanding. Our research may be somewhat biased, as few would admit to not regularly developing themselves. Trainers need methodological support in teaching different age groups and adults with different motivations/skills. Adult learning experts can support adult learning institutions in this field and consider it necessary to develop themselves in this regard through further professional training.

According to the opinion of the trainers and experts, it is feasible and beneficial to develop a benchmarking tool that can determine the digital awareness and digital skills of trainees. Several of them indicated that such 
an assessment can be effectively combined with appropriate competence development. The future direction of adult learning is to develop a different methodology for different generations, using tools customized for the generations/IT awareness. Information should be made available at different technological levels and the incomers should be empowered to receive it.

Feedback from experienced trainers suggests that in many cases, the older generation is much more motivated and, despite their modest digital competencies, more actively involved in the educational process. The younger generations are surrounded by so much information that in many cases they cannot set objectives and stay focused. The epidemic situation has generated methodological tools - mostly of the blended-learning type - in adult education institutions, the use of which is both appropriate and fruitful for the future. This type of training is time- and cost-saving and its effectiveness can be enhanced if it is complemented by appropriate face-to-face consultation and practical training.

\section{Conclusions}

Overall, the future lies in adult learning based on individual needs, in terms of time and methodology, supported by appropriate technical support in the case of on-the-job training, while in the case of practical training, the participant's level of knowledge is involved in the training process.

For trainers, it is worth creating an adult education channel that supports professional-methodological knowledge, where they can continuously learn the communication techniques, tools, and methods required by the generations.

For those entering adult education - and especially for adult education institutions and organizations - it is advisable to develop a "test" exploring digital skills and abilities, which will assist in the selection and application of the appropriate methodology. This test can be connected with the preliminary test developed in our previous research to identify the lack of basic skills. In this way, a full picture could be obtained of what prior development is needed to master the curriculum and what "channels" are most effective for delivering the training.

In addition to the above, supporting the will of adult education institutions and the knowledge of those working in education, it is necessary to help the actors, partially or entirely, to develop and continuously update digital learning materials (according to the needs of Industry 4.0) and to provide the technical conditions for the present education according to the requirements of the $21^{\text {st }}$ century.

\section{References}

Blomqvist, I. - Ruuskanen, T. - Niemi, H. - Nyyssönen, E. 2000. Participation in adult education and training in Finland Adult Education Survey, Statistics Finland. https://www.tilastokeskus.fi/tup/julkaisut/tiedostot/isbn 952-467-140-9 en.pdf, 2021, 10.23.

Brady, H. E. - Elms, L.1999. Age-period-Cohort Analysis with Noisy, Lumpy Data. Working paper, prepared annual meeting of the political methodology group of the American Political Science Association. 1999.

Cséfalvay. 2017. A nagy korszakváltás. (Techtronic Shifts), Kairosz Kiadó, 2017, p. 430.

Dinas, E. - Stoker, L. 2014. Age-Period-Cohort Analysis: A design-based approach. In Electoral Studies, http:/dx.doi.org/10.1016/j.electstud.2013.06.006

Földházi, Á. 2018. Az alfáktól az ómegáig - Interjú Nemes Orsolya generációkutatóval (From alpha to omega - Interview with Orsolya Nemes, generation researcher), A Sziv, 2018. május. https://jezsuitakiado.hu/cikkek/az-alfaktol-az-omegaig/, 2019, 07. 10.

Jogi, L. - Gross, M. 2009. The Professionalisation of Adult Educators in the Baltic States. In European Journal Education Research, Development and Policy. https://doi.org/10.1111/j.1465-3435.2009.01380.x, 2021, 10.23.

Jõgi, L. - Teresevičienė, M. - Koke, T. - Carlsen, A. 2018. Nordic-Baltic cooperation in the field of adult education 1991-2004. In International Review of Education, 2018, no. 64, pp. 415-419.

Komár, Z. 2017. Generációelméletek (Generational theories). Új Köznevelés (New Public Education), 2017, no. 73. pp. 8-9.

https://folyoiratok.ofi.hu/uj-kozneveles/generacioelmeletek, 2021. 05.21.

Meretei, B. 2017. Generációs különbségek a munkahelyen - szakirodalmi áttekintés (Generational differences at work - a literature review). In Vezetéstudomány (Management science), vol. XLVIII, no. 10, pp. 10-18. https://doi.org/10.14267/VEZTUD. 2017.10.02

Pais, 2021. Y és $Z$ generáció mint a jövő munkavállalói (Generation Y and $Z$ as the future workforce), Felsőoktatási jelentkezési lap kitöltési útmutató (Guide for filling in the higher education application form). https://www.kormanyhivatal.hu/ download/2/18/60000/Y\%20\%C3\%A9s\%20Z\%20gener\%C3\%A1ci\%C3\%B3\%20 mint $\% 20 \mathrm{a} \% 20 \mathrm{0} \%$ C3\%B6v\%C5\%91\%20munkav\%C3\%A1lla|\%C3\%B3i.pdf, letöltve: 2021. 04. 10.

Skorobogatov, G. 2015. Adult Education and Training in Estonia, EPALE, Resource Details. https://epale.ec.europa.eu/en/resource-centre/content/adult-education-andtraining-estonia, 2021, 10.23.

Szűcs, K. - Törőcsik, M. - Bittner, Z. 2015. A korai Z és a késői Y generáció jellemzői (Characteristics of early Generation $Z$ and late Generation Y). In Töröcsik, M. Dr. (szerk): $A Z$ generáció magatartása és kommunikációja (Generation $Z$ behaviour and communication), Pécs : Pécsi Tudományegyetem, 2015, pp. 66-87.

Windship, C. - Harding, D. J. 2008. A mechanism-based approach to the identification of Age-Period-Cohort models, Sociological Methods and Research.

\section{Contact address}

Malatyinszki Szilard, Kodolanyi Janos University, H-8000, Hungary, Szekesfehervar, Furdo str. 1., phone: +36-30-445-6943, e-mail: mszilard@ kodolanyi.hu 